\title{
Potatoes Value Chain Analysis and Development in River Nile State of Sudan
}

\author{
Elgilany A. Ahmed", Hamid H. Faki, Abbas Elsir, Hanadi Elfadil, Abaker Ismail
}

\author{
Agricultural Research Corporation, Agricultural Economics and Policy Research Center, Sudan \\ *Correspondence: elgilanya@yahoo.com
}

\author{
Received on: 22/9/2020
}

Accepted on :20/12/2020

\begin{abstract}
Now days world wide increased concern about developing the major food-cash crops production to meet the demand of population growth and farms sustainability. Potato crop is one of the most potential crops in River Nile State that can achieve this purpose. This research aims to describe the potatoes value chain analys is and development. It depends on primary and secondary data. The study applied an approach dependent on compiling theoretical knowledge of value chain analysis basics along with intensive fieldwork and includes comprehensive interviews with a total of 44 producers, 19 wholesalers, 35 retailers, 2 cold storages managers and 34 consumers were interviewed. The actors in the crop chains to present an integrated detailed of all the key actors and players along with the vertical correlations and relations that control the operation and process inside potatoes chains. The field survey in area of the study undertook four major dis tricts along the State specializing in production of potatoes. The value chain analys is showed that, at the level of marketing, there are inadequate cold storages for preserving potatoes, poor extension services at different levels of the crop chain. However, to tackle these constraints, cooperation of stakeholders implying national and international agricultural organizations, governmental institutions and private sector would enhance farming system sustainability of the crop.
\end{abstract}

KEYWORDS: potatoes, value chain, River Nile State, Sudan

\section{INTRODUCTION}

Potatoes (Solanum tuberosum L.) are tubers that are a staple food in many parts of the world, particularly Europe and the West. Potato is a major vegetable crop and the third most important after wheat and rice in terms of production and consumption worldwide (FAO, 2012). They are commonly categorized according to when they're harvested (early, mid-season and late) as well as their characteristics (whether waxy in appearance, or floury once cooked). All-rounder varieties include King Edward, Maris Piper, Romano and Desirée potatoes, which are suitable for every type of cooking except for salads and steaming. In Sudan potatoes production is a relatively recent agricultural activity, starting in Khartoum and later spreading to other parts of the country. The most potent states of potatoes production might include River Nile, Northern, Kassala and Gezira (Algizouli, 2000). The country witnessed that the majority of the population is living under poverty line. Due to predominant of poverty incident, the major portion of population is unaffordable to purchase and consume quality nutritious food items.
Malnutrition and poor health are dominated among people, resulting low productivity of labor force and less development. Accordingly, the crop is considered as one of the most important food and cash crop. It contributes significantly to the daily diet of Sudanese people. Moreover, it plays an important role in sustaining the farming systems through its high returns. Among short duration crops, potatoes farming are considered one of the most feasible ventures. The selection of this state was based on the crop pattern and crop combinations represented by seasonal field crops as well as it large arable acreages endow ments that occupied by high number of tenants. The location of the state is about 300 kilometers north Khartoum, the district has chosen rather than whole of the State to restrain time and money. Potatoes in River Nile State depend mainly on surface irrigation from River Nile. The climate there is relatively cool in winter that extends from October to March. The state is enjoyed with alluvial fertile soils, while the environment is rather favorable for producing relatively high-value crops compared to other states of the country. The crop is grown in the state in the winter season, it begins in November and continues into March, it 
prevailed along the River Nile banks as well as in the islands existed along the River Nile. Potato crop in the State is commonly produced under irrigated sector from the River Nile. Generally, demand and consumption of potatoes increase during the postharvest where the crop pric es often low with high crop supply resulting demand increase for annual cool storage. Bearing in mind the importance of potatoes in rural economy, the present research was carried out to present a clear mapping and analysis of potatoes subsector value chains and development in River Nile State, North Sudan. Specifically it aims to investigate the challenges and the main factors constraining the potatoes value chains from achieving increased yield and full commercialization, also to examine routes for sustainable change in potatoes farming system and that increase market opportunities along the crop value chains, in addition to identify opportunities and advantage points in the potatoes market system for interventions and development.

\section{MATEREALS AND METHODES}

This research carried-out in the River Nile State (RNS) of North Sudan. The climatic conditions of the State allow the production of a wide range of annual crops. The total area of the River Nile State is estimated at $129.744 \mathrm{~km}^{2}$ (30 million fed) out of which about 9,500,000 feddan is a categorized as agricultural arable land, while the current invested land is about 1,200,000 feddan and 3,249,000 fed is certified land for agricultural investment and suitable for multi agro-activities and crop production (see Table 2). On the other hand, the State is one of the relatively rich states in the country in water resources. The main direct resources of irrigation water in RNS are the River Nile, Atbara River, underground water and rains as shown in Table 2 (see Figure 1).

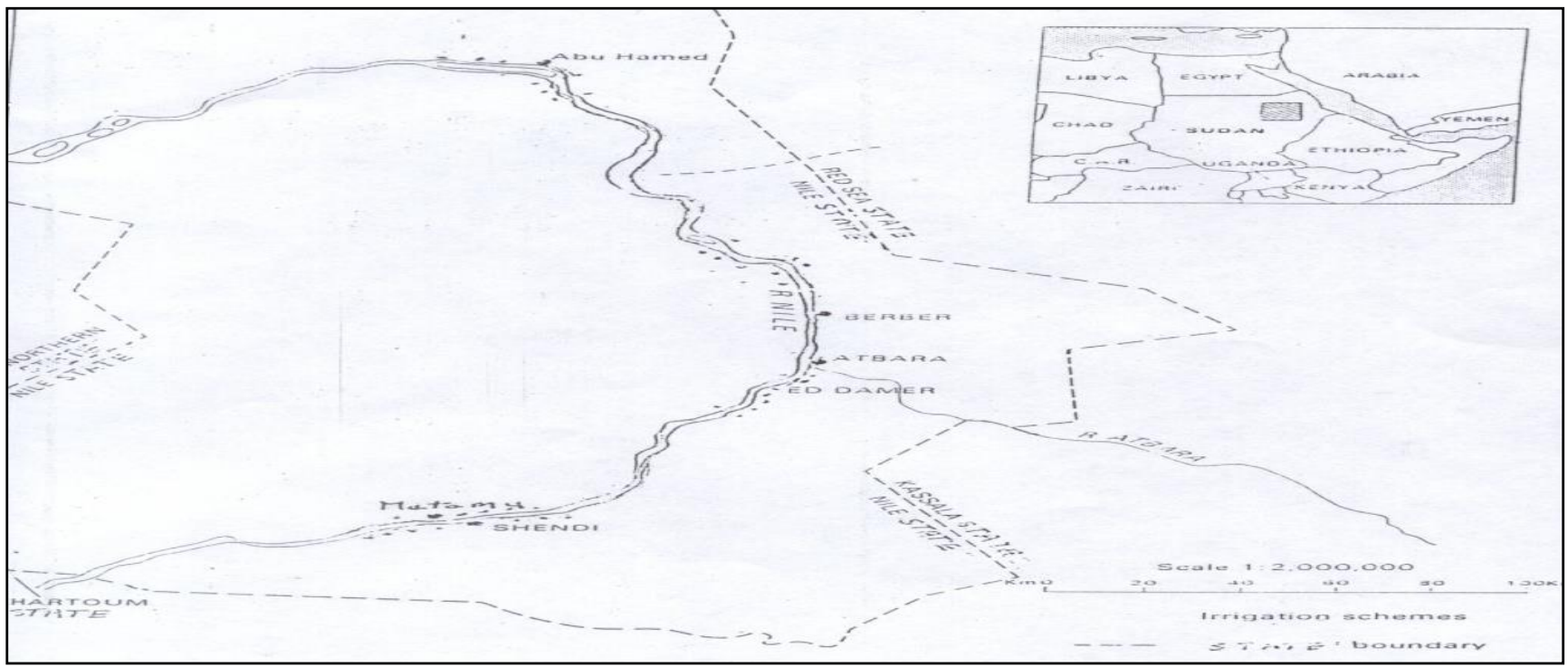

Source: Ahmed 2004

Figure 1. Map of the River Nile State of North Sudan

The primary data collected by using structural questionnaires, it was largely qualitative, using key informant interviews and observations. The primary data covered technical, social and economic aspects of potatoes production in area of the study. While the secondary data and literature review emphasized on an analysis of the market system supporting the core value chain at different levels. FAO (2015) defined these various levels of value chain and the market system that including the micro-level: core valuechain actors as well supporting suppliers of goods and services at production and post-production levels, macro-level: people facilitating polices, laws and regulations governing business in the sector), meta- level: people influencing other people's views about potatoes, and the. This process also helped identify data gaps during the field research, which targeted people growing, trading, processing, wholesaling, retailing and consuming potatoes as well as those providing various services to all these value chain actors.

\subsection{Analytical techniques}

Qualitative analysis was used, it was chosen because there is little quantitative data about the potatoes marketing in the area of the study. Generally, a set of techniques were applied to achieve the goals of the study. Descriptive statistical analysis and partial 


\section{Scientific Journal of Agricultural Sciences 2 (2): 158-176, 2020}

budget analysis were used. In this part of the analysis, graphical, frequency distribution and statistical analysis was applied. This research is based on indepth respondents conducted in River Nile State in Feb. 2018. The surveyed potatoes growers and actors took place in four localities in the State, namely Shendi, Eddamar, Atbara and Berber. The selection of potatoes actors was based on their involvement and expertise in potatoes production and business.

The applied statistical analysis used the collected data from the field survey and other relevant formal sources. They were found to be relevant to attain the objectives of the study and they enabled interpretation and discussions on the research topics and themes. To achieve the proposed fieldwork, a team of five persons was formed from the State Ministry of Agriculture who use to participate in various researches and similar studies of crop value chains, based on their experiences and backgrounds as agricultural economists and field researchers. The surveyed respondents were contacted first by the team and inform them briefly about the purpose of the study and informed how the research policy recommendation would be used and benefit, and concluded by setting up an interview. The venue for the meetings was often the workplace of the interviewers; this will make the respondents feel comfortable to talk and provide the required information. The surveyed respondent consisted of potatoes growers, wholesalers, retailers, managers of cool storages, and consumers as illustrated in Table 1. All of the respondents were from the area of the study. Table 1. The actors and respondents of the field survey

\begin{tabular}{lc}
\hline \multicolumn{1}{c}{ Actors } & Number of Actors \\
\hline Potatoes growers & 44 \\
cold storages managers & 2 \\
Wholesalers & 19 \\
Retailers & 35 \\
Consumers & 34 \\
\hline
\end{tabular}

\section{RESULTS AND DISCUSSION}

The value chain of potatoes like any value chain of strategic crops, it implies production inputs suppliers and banks and financial institutions. These institutions are represented in the area of the study mainly by the Agricultural Bank of Sudan (ABS), the Ministry of Agriculture and Ministry of Finance. They have continually provided financial and technical support to rural agriculture in these areas such as agricultural credit provision, production inputs, machineries, access to markets, rehabilitation of irrigation sector and others. In spite of this efforts and progress observed in the last decades, the technological gap between private and public sector as well as large-scale and small-scale farmers persists.

The farmers in the agricultural schemes of RNS seek every season to develop their farming system and to adopt new relevant agricultural technologies. They aim to manage a suitable crop rotation that contributes to irrigation water and land use efficiency and soil conservation. In addition, they look to apply advance technologies to manage a reliable crop combination based on legumes crops (i.e. alfalfa, broad bean) and grains (i.e. wheat). The agricultural production in the State faced by some hindrances includes inadequate finance, lack of information and awareness, and poor agricultural policies; they constrain the application of agricultural advance technologies and cause the slow adoption process among public irrigated schemes and small farmers. Bardhan and Udry (1999) reported that, lower adoption rates are generally associated with imperfections in credit markets, information, agroecological characteristics, input and output markets as well as inadequate incentives associated with farm tenure arrangements, problems mainly observed in developing countries.

\subsection{Potatoes Value chain mapping in River Nile State}

The study covers the technical, financial, marketing and processing aspects of potatoes value chain, performance about production aspects, potatoes quality, and gained profits among different actors of potatoes value chain in the State. The State policies are also a fundamental part of the enabling environment of the crop value chain, and from that section a few data was collected about government policies from some annual reports. It is the results of a fieldwork and a documentation review. This research focuses on potatoes value chain analysis, development and mapping of the crop chain, and identifying the production constraints, bottlenecks as well as the opportunities for potential areas of intervention for value chain development that could be addressed in the future. The study provides a complete value chain analysis for potatoes starting from production inputs to the stage of consumption. It also emphasizes and evaluates the different potatoes chains and provides a market analysis of the product flow. The study addressed the value chain mapping of the crop to enables us to visualize the flow of potatoes product from inputs companies (i.e. Seed Company) to end consumers along the different actors of the crop. 
Elgilany A. Ahmed et al.,2020

Figure 3: Potatoes Value Chain Mapping in River Nile State

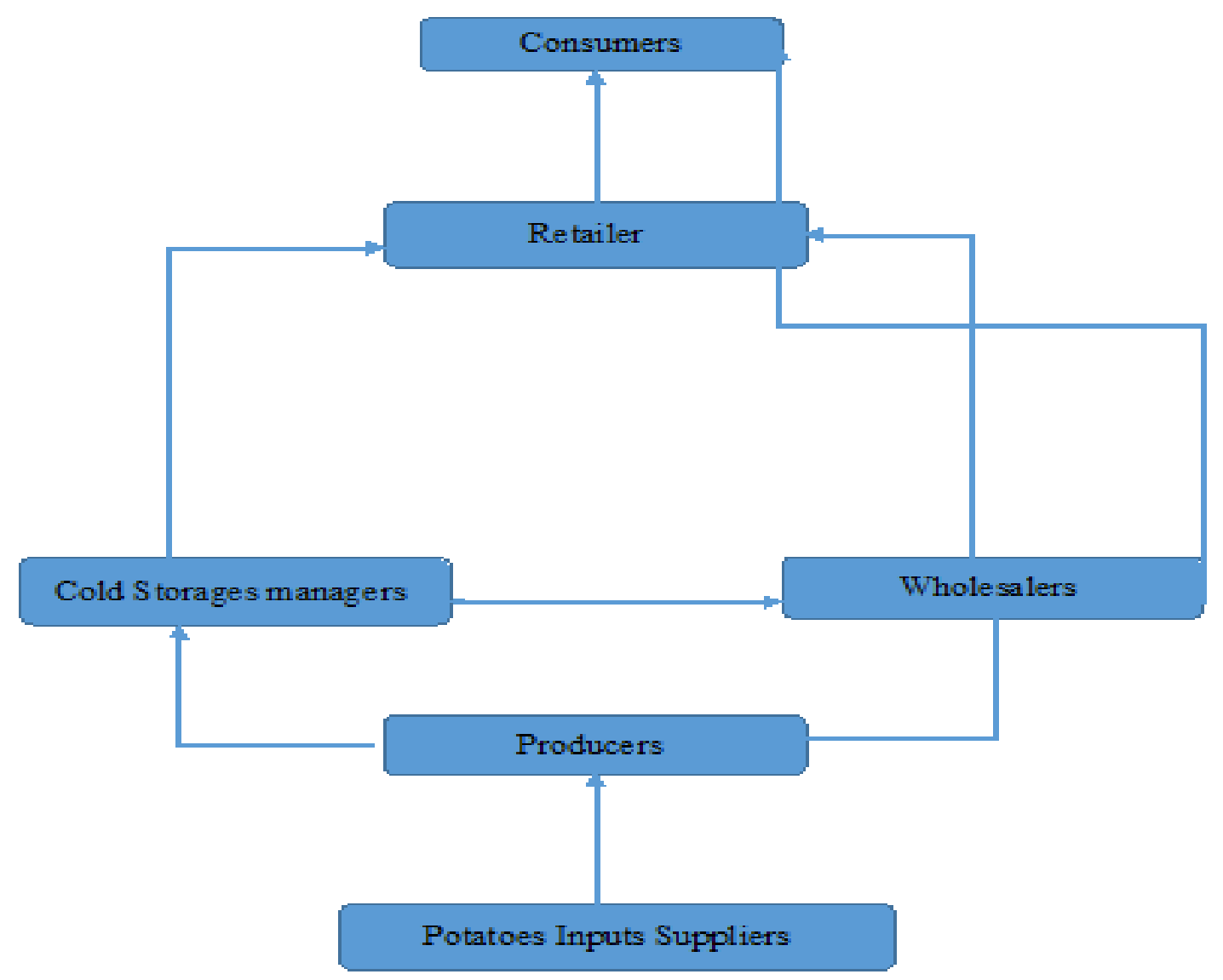

Source: Field survey, 2019.

Fig.3 shows the value chain mapping of potatoes in River Nile State. It presents the different actors in the value chain including inputs suppliers, potatoes growers or producers, wholesalers (in rural areas and central cities), cold storage owners, retailers and consumers. From the structure aspect of potatoes value chain, the information enlightens potatoes product differentiation and the dominant vertical coordination. The conduct of the potatoes industry in area of the study was perhaps the absent part to be examined may be due to dominant conventional use, but other information regarding pricing behavior, and actors' performance was gathered.

\subsection{Socio-economic characteristics of potatoes VC actors in the State}

The study undertook an analysis of some socioeconomic characteristics including mainly locality, occupation, age, education level and experiences for the surveyed potatoes actors. Table 3 and Table 4 represent these characteristics.

Locality: The study revealed that $54.5 \%$ of potatoes growers of the crop value chain live in Shandi locality, while Elddamr showed $34.1 \%$ and Barbr just $11.4 \%$. But in Table 4 the majority of the wholesalers and retailers live in Atbara and Elddamr (68.4 and 62.9 respectively), $52.9 \%$ of the consumers live in Elddamr. Occupation: Table 3 unveiled that $81.8 \%$ of the producers mentioned that their basic occupation is agricultural activities and $18.2 \%$ of them have additional work. On the other hand, wholesalers and retailers reported that their basic occupation is trade of the potatoes ( $94.7 \%$ and $74.3 \%$ respectively). 
Scientific Journal of Agricultural Sciences 2 (2): 158-176, 2020

Table 3. Distributions of producers and cold storage owner according to Socio-economic characteristics

\begin{tabular}{|c|c|c|c|c|c|}
\hline \multicolumn{2}{|c|}{ Variable } & \multicolumn{2}{|c|}{ Producers } & \multicolumn{2}{|c|}{ Cold storage owner } \\
\hline Locality & Items & Frequency & Percent & Frequency & Percent \\
\hline & Shendi & 24 & 54.5 & - & - \\
\hline & Aldamr & 15 & 34.1 & 1 & 50.0 \\
\hline & Brbr & 5 & 11.4 & 1 & 50.0 \\
\hline & Total & 44 & 100.0 & 2 & 100.0 \\
\hline Your & Yes & 36 & 81.8 & 2 & 100.0 \\
\hline Occupation & No & 8 & 18.2 & - & - \\
\hline & Total & 44 & 100.0 & 2 & 100.0 \\
\hline Age & Less than 20 & 0 & 0 & - & - \\
\hline & $21-30$ & 3 & 6.8 & 2 & 100.0 \\
\hline & $31-40$ & 11 & 25.0 & - & - \\
\hline & $41-50$ & 10 & 22.7 & - & - \\
\hline & $51-60$ & 12 & 27.3 & - & - \\
\hline & More than 60 & 8 & 18.2 & - & - \\
\hline & Total & 44 & 100.0 & 2 & 100.0 \\
\hline Education & Khalowa & 3 & 6.8 & - & - \\
\hline Level & Primary & 16 & 36.4 & - & - \\
\hline & Basic & 7 & 15.9 & - & - \\
\hline & Secondary & 18 & 40.9 & - & - \\
\hline & University & - & - & 2 & 100.0 \\
\hline & Total & 44 & 100.0 & 2 & 100.0 \\
\hline
\end{tabular}

Source: field survey, 2020

Table 4. Distributions of wholesalers, retailers and consumers according to Socio-economic characteristics

\begin{tabular}{llcccccc}
\hline Variable & & Wholesalers & \multicolumn{3}{c}{ Retailers } & \multicolumn{3}{c}{ Consumers } \\
\hline Locality & Items & Frequency & $\%$ & Frequency & $\%$ & Frequency & $\%$ \\
\cline { 2 - 7 } & Abdra & 13 & 68.4 & 22 & 62.9 & 16 & 47.1 \\
& Aldamr & 6 & 31.6 & 13 & 37.1 & 18 & 52.9 \\
Occupation & Total & 19 & 100.0 & 35 & 100.0 & 34 & 100.0 \\
& Yes & 18 & 94.7 & 26 & 74.3 & - & - \\
& No & 1 & 5.3 & 9 & 25.7 & - & - \\
Age & Total & 19 & 100.0 & 35 & 100.0 & - & - \\
& Less than 20 & 1 & 5.3 & 3 & 8.6 & 1 & 2.9 \\
& 21 - 30 & 4 & 21.1 & 8 & 22.9 & 9 & 26.5 \\
& 31- 40 & 3 & 15.8 & 16 & 45.7 & 12 & 35.3 \\
& 41 - 50 & 5 & 26.3 & 5 & 14.3 & 9 & 26.5 \\
& 51 - 60 & 4 & 21.1 & 3 & 8.6 & 2 & 5.9 \\
Educationyyyyyyyyy & More than 60 & 2 & 10.5 & 0 & 0 & 1 & 2.9 \\
& Total & 19 & 100.0 & 35 & 100.0 & 34 & 100 \\
& Khalow & 2 & 10.5 & 3 & 8.6 & 4 & 11.8 \\
& Primary & 4 & 21.1 & 6 & 17.1 & 3 & 8.8 \\
& Basic & 6 & 31.6 & 12 & 34.3 & 1 & 2.9 \\
& Secondary & 4 & 21.1 & 9 & 25.7 & 3 & 8.8 \\
& University & 3 & 15.8 & 5 & 14.3 & 19 & 55.9 \\
& University+ & 0 & 0 & 0 & 0 & 4 & 11.8 \\
& Total & 19 & 100.0 & 35 & 100.0 & 34 & 100 \\
\hline
\end{tabular}

Source: field survey, 2020

Age: The research unveiled that the majority of which are the most active group while the others were producers were under age groups $31-40$ and $51-60$ found as less than 20 and more than 60 represented 
less share. In the Table 4 wholesalers were dominant under age groups $41-50$ and $51-60$ that is refer to the experiences while the retailers were dominant under age groups $21-30$ and $31-40$.

Education level: Table 3 shows that $40.9 \%$ of the producers have attended secondary school and $36.4 \%$ basic school, it's noticed that only $6.8 \%$ were "khalowa" that indicated high awareness of the producers in cultivation potatoes in the State, while Table 4 shows that the majority of wholesalers and retailers were educated.

Experiences: From Table 5 the average experience years for producers, wholesalers and retailers were $12.2,18.0$ and 14.6 years respectively.

owners (see Table 5).
Table 5. Distributions of potatoes actors according to the experiences years

\begin{tabular}{lll}
\hline Variable & Experiences of years & \\
\cline { 2 - 3 } & Mean & SD \\
\hline Producers & 12.22 & 10.912 \\
Wholesalers & 18.00 & 11.728 \\
Retailers & 14.05 & 9.959 \\
Cold storages owners & 6.00 & 5.656 \\
\hline
\end{tabular}

Source: field survey, 2020

\subsection{Traders}

The traders play a significant role in the crops value chains, they usually buy from producers on a short-sell basis (i.e. they book the crop around the start of the season and pay cash). They procure the crop and pass the marketable surplus of that crop up to wholesalers, retailers, and processors.

Wholesalers could perform purchase from producers through agents. There are numerous stakeholders working in developing potatoes subsector in Sudan. Most of them are considered as private sector and the international organizations also took place in upgrading potatoes sub-sector. The main stakeholders that active in the potatoes sub-sector in the country are Agricultural Research Corporation (ARC) of Central Ministry of Agriculture and Forestry, the Agric ultural Development Corporation of Merowe Dam and the Food Research Center of Central Ministry of Agriculture and Forestry. The mentioned stakeholders are carrying out different types of activities comprise processing. Agricultural Research Corporation (ARC) and the Technology Transfer administration of Central Ministry of Agriculture and Forestry provide extension services to producers related to research studies on potatoes seeds and new varieties, potatoes pests and diseases, agrotechnical packages, as well as related extension services.

\subsection{Value chain actors of potatoes in River Nile State}

The crop value chain process begins usually by contacting financial institutions in case of looking for agricultural finance otherwise the crop grower will communicates with input suppliers who normally supplying chemical (i.e. pesticides, fertilizers), seedlings, farm tools and equipments and others. Private firms are active in providing chemical inputs and packing material. The value chain of crops might include numerous types of actors beside financial institutions and input suppliers namely producers, traders, retailers, wholesalers, processors and exporters, in this research the main actors are producers, retailers, wholesalers and cold storages

owners (see Table 5).

\subsection{Producers}

Small-, medium- and large-scale privates producers and big companies; tenants in quasigovernment schemes; mostly traditional production concentrated along the River Nile banks as well as in eastern, central and western States of the country. Potatoes are grown mainly by vegetables farmers, average allocated area for potatoes is found as 17.43 fed per producer of the State. The most famous areas of producing potatoes in River Nile State were namely, Altragma, Alkityab, Almtama, Alsnahir Alnyha island, Almosiab and Alzidab, while the most common variety grown called Zafera and Bilina and the average yield of potatoes achieved by the crop growers was about $166.43 \mathrm{sack} / \mathrm{fed}$. Table 6 shows some of essential inputs of potatoes including land tenure type, potatoes seeds input, sources of finance, sources of potatoes seeds.

Land tenure type: according to Table 6 that $70.5 \%$ of land was rented and $27.3 \%$ was owned, while only $2.3 \%$ of the land was shared.

Type of potatoes seeds input: The research revealed that the greatest portion of producer's $(45.5 \%)$ preferred local seeds varieties from market, while about $43.2 \%$ of them planted local seeds mixed with imported seeds, and the minority of the producers 
Scientific Journal of Agricultural Sciences 2 (2): 158-176, 2020

(11.4\%) planted imported seeds, due to high price of the imported seeds (see Table 6).

Sources of potatoes seeds: From Table 6, about $38.6 \%$ of the potatoes producers obtained their seeds from the local and central markets, while $31.8 \%$ of them have obtained it from Seeds Companies and a few of them obtained it either from cold storage owners or Agricultural Bank of Sudan (ABS) for $20.5 \%$ and $6.8 \%$ respectively (see Table 6 ).

Table 6. Distribution of producers according to type of land, seeds and finance

\begin{tabular}{llcc}
\hline & Variables & \multicolumn{2}{c}{ Producers } \\
\hline Land tenure type & Items & Frequency & Present \\
\cline { 2 - 4 } & Owner & 12 & 27.3 \\
& Rent & 31 & 70.5 \\
& Share & 1 & 2.3 \\
& Total & 44 & 100.0 \\
Type of Potatoes seeds input & Local & 20 & 45.5 \\
& Imported & 5 & 11.4 \\
& Local \& Imported & 19 & 43.2 \\
Sources of potatoes seeds & Total & 400.0 \\
& From market & 44 & 38.6 \\
& Freezing owner & 17 & 20.5 \\
& Seeds company & 9 & 31.8 \\
& Wholesalers & 14 & 2.3 \\
& Agricultural Bank & 1 & 6.8 \\
& Total & 3 & 100.0 \\
& Self-funding & 44 & 59.1 \\
& Share & 26 & 22.7 \\
& Agricultural company & 10 & 4.5 \\
& Agricultural Bank & 2 & 9.1 \\
& Friends and relative & 4 & 2.3 \\
& Other & 1 & 2.3 \\
& Total & 1 & 100.0 \\
\hline
\end{tabular}

Sources: field survey, 2020

Sources of finance: The study unveiled that $59.1 \%$ of the producers under the study were reported as self-finance while $9.1 \%$ of them have received finance from the Agricultural Bank of Sudan (ABS) due to complicated procedures at financial institutions in the country.

Type of potatoes fertilization in the State: Figure 4 illustrates some type of the fertilizer to be used by potatoes growers in the State

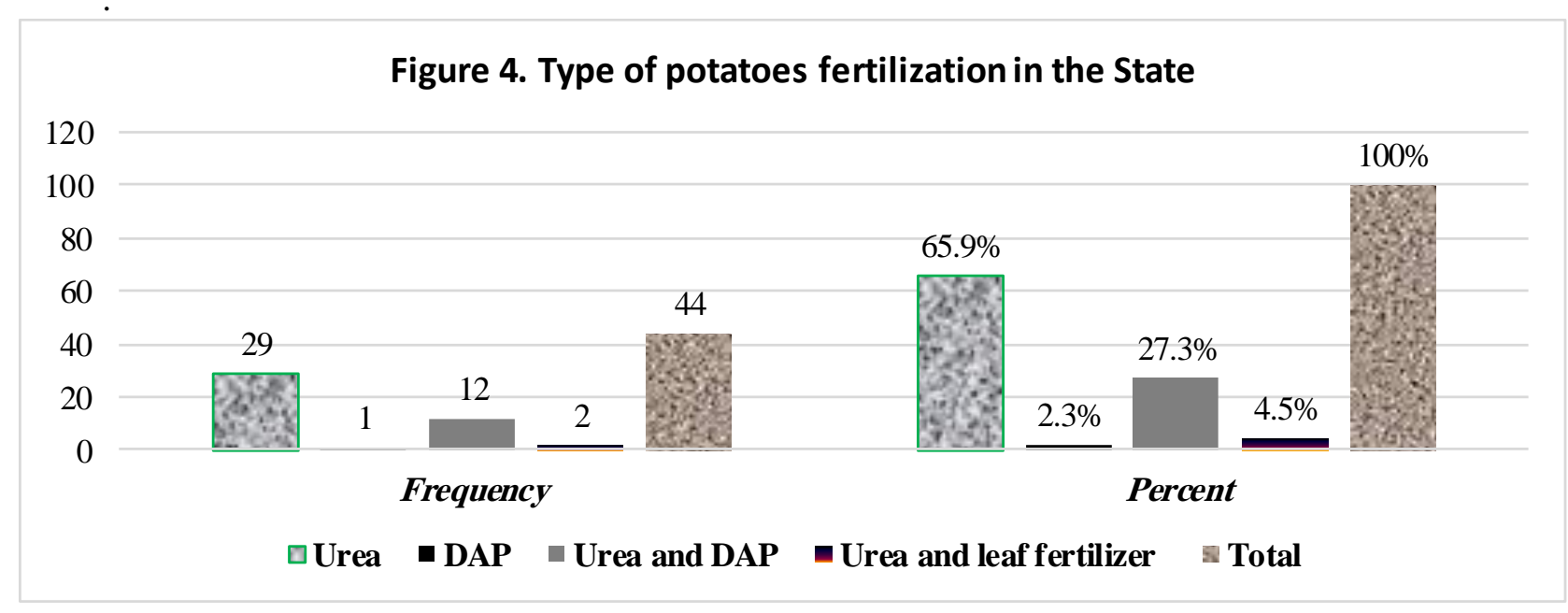


The figure shows that the majority of producers $(65.9 \%)$ were used Urea while $27.3 \%$ of them used Urea mixed with DAP and $4.5 \%$ of them used Urea with leaf fertilizer and only $2.3 \%$ of them used DAP.

Sources of the fertilizer for potatoes: From the Figure 5 that $63.6 \%$ of the potatoes producers obtained fertilizer for potatoes from local and central cities markets, while $18.2 \%$ them brought it from seeds companies, and $11.4 \%$ from the market with agricultural bank and only $6.8 \%$ of them obtained it Agricultural Bank.

On the other side Table 7 depicts the distribution of fertilization for potatoes crop according to quantity and prices (sack/fed) in River Nile State.

Table 7. Distribution of the fertilization of potato according to quantity \& prices (sack/fed)

\begin{tabular}{ccc}
\hline Variable & \multicolumn{2}{c}{ Fertilization } \\
\cline { 2 - 3 } & Mean & SD \\
\hline Quantity (sack) & 4.06 & 1.917 \\
Prices (SDG) & 1566.27 & 289.000 \\
\hline
\end{tabular}

Sources: field survey, 2020

Figure 5. Sources of the fertilizer for potatoes in the State

120

$100 \%$

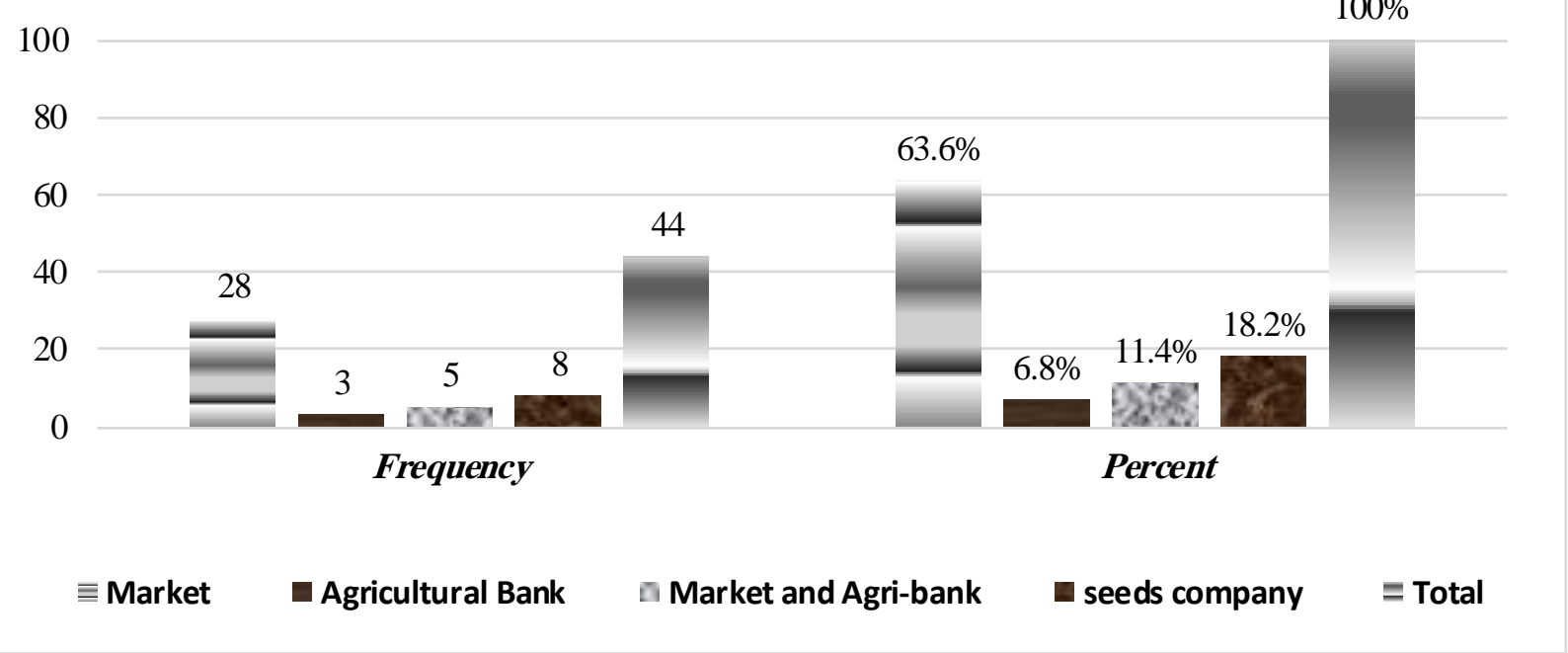

Sources: field survey, 2020

From Table 8 that the highest cost component recorded $w$ as for obtained seeds which was accounted for $59.79 \%$ of the total costs for one fed, while $10.01 \%$ for the fertilizer and $9.22 \%$ for the cost of land rents for cultivation of fed of potato.

\subsection{Cold storage owners}

Table 9 illustrates the distribution of the cold storage ownership according to the type storage ownership and locations of potatoes crop production, in addition it represents the suitable markets that intake the surplus of potatoes as well as sources of crop purchase and showed who sell the crop and who provide finance to potatoes growers to obtain their crops after harvest.

Type of cold storage ownership: For the cold storage ownership in the area of the study, the results show that $100 \%$ of the cold storage owned by wholesalers of potatoes in the State. The research revealed locations for production potato crop: it shows that $50 \%$ of the cold storage owners from Almhmia and Barbr locality, and $50 \%$ of them same percentage from Shendi and Elddamr, while the markets of potatoes in the State were included cold storage owners who obtained potatoes directly from potatoes producers as well as from central markets of the State such as Almhmia, Barbr, Shendi and Elddamr of the State. 
Scientific Journal of Agricultural Sciences 2 (2): 158-176, 2020

Table 8. Costs and returns potatoes production obtained by the producers (SDG/fed)

\begin{tabular}{|c|c|c|c|}
\hline Revenues and costs & Mean (sack/fed) & $(\%)$ & Mean (for one ton) \\
\hline \multicolumn{4}{|l|}{ Revenues: } \\
\hline Productivity (sack/fed) & 166.43 & & 1.00 \\
\hline Prices of potato (SDG/ sack) & 600.11 & & 12,000 \\
\hline Return of potato (SDG/fed) & $99,876.30$ & & 12,000 \\
\hline Total of revenues (SDG/fed) & $99,876.30$ & & 12,000 \\
\hline \multicolumn{4}{|l|}{ Costs: } \\
\hline Rent & 5854.54 & 9.22 & p. \\
\hline Seeds & 37982.81 & 59.79 & p. \\
\hline Fertilizer & 6359.05 & 10.01 & p. \\
\hline Tilling & 1271.48 & 2.00 & p. \\
\hline Total production cost & 51467.88 & & 6185 \\
\hline Prepare & 1131.73 & 1.78 & o. \\
\hline Cultivation & 1757.73 & 2.77 & o. \\
\hline Weeding & 1619.68 & 2.55 & o. \\
\hline Irrigation & 757.73 & 1.19 & o. \\
\hline Harvesting & 3008.95 & 4.74 & o. \\
\hline Transport & 3072.27 & 4.84 & o. \\
\hline Load & 684.20 & 1.08 & o. \\
\hline Taxes & 30.57 & 0.05 & o. \\
\hline Total operation cost & 12062 & & 1450 \\
\hline Total costs & $63,530.74$ & & $7,634.529$ \\
\hline \multicolumn{3}{|c|}{ (as a proxy for purchase price) } & (Total costs for one ton) \\
\hline Net Returns & $36,345.56$ & & $4,365.471$ \\
\hline
\end{tabular}

Sources: field survey, 2020

Table 9. Distribution of the cold storage ownership according to the type and locations

\begin{tabular}{|c|c|c|c|}
\hline \multicolumn{2}{|l|}{ Variable } & \multicolumn{2}{|c|}{ Freezing wholesalers } \\
\hline \multirow{4}{*}{$\begin{array}{lll}\text { Type of } & \text { cold } & \text { storage } \\
\text { ownership } & & \end{array}$} & Items & Frequency & Percent \\
\hline & Owner & 2 & 100.0 \\
\hline & Rent & 0 & 0 \\
\hline & Total & 2 & 100.0 \\
\hline \multirow{3}{*}{$\begin{array}{l}\text { Locations for production } \\
\text { potato crop }\end{array}$} & Almhmia and Brbr & 1 & 50.0 \\
\hline & Shendi and Aldamr & 1 & 50.0 \\
\hline & Total & 2 & 100.0 \\
\hline \multirow{3}{*}{$\begin{array}{l}\text { Markets which is obtained } \\
\text { potato in this season. }\end{array}$} & Almhmia and Brbr markets & 1 & 50.0 \\
\hline & Shendi and Aldamr markets & 1 & 50.0 \\
\hline & Total & 2 & 100.0 \\
\hline \multirow{3}{*}{$\begin{array}{l}\text { Sources of potatoes crop } \\
\text { purchase. }\end{array}$} & Trader & 1 & 50.0 \\
\hline & Other farmers & 1 & 50.0 \\
\hline & Total & 2 & 100.0 \\
\hline \multirow[t]{2}{*}{ For who sell the crop } & Wholesalers & 2 & 100.0 \\
\hline & Total & 2 & 100.0 \\
\hline \multirow{3}{*}{$\begin{array}{l}\text { Do you finance the potatoes } \\
\text { producers to obtain the crop }\end{array}$} & Yes & 1 & 50.0 \\
\hline & No & 1 & 50.0 \\
\hline & Total & 2 & 100.0 \\
\hline
\end{tabular}

Source field survey, 2020

The study unveiled that the main sources of potatoes crop to be purchased by cold storage owners in the River Nile State were found that $50 \%$ of the cold storage owners purchase the crop from trade in the markets, while $50 \%$ of them purchase from other producers. It's clear that there are different sources for purchasing the crop in the area of the study. In addition, the research depicted the main buyers of potatoes were illustrated in Table 9 that $100 \%$ of the cold storage owners sell the crop to the potatoes 
wholesalers. This means that the cold storage owners deal with the high quantity and big sizes of potatoes marketable surplus. The research also evaluated the impacts of actors finance on potatoes marketing, it showed that $50 \%$ of the cold storage owners finance producers under the condition of obtaining the crop after harvest, while $50 \%$ of the cold storage owners did not support or provide any finance to the potatoes growers.

Table 10 depicts the distribution of cold storage owners for capacity of their cold storages (sack), and also it shows the withdrawn quantity during a month per sack in River Nile State.

Table 10. Distribution cold storages capacity and withdrawn quantity per month (sack)

\begin{tabular}{lll}
\hline Variable & \multicolumn{2}{l}{ cold storage owners } \\
\cline { 2 - 3 } & Mean & SD \\
\hline Capacity of cold storages (sack) & 1250.00 & 353.553 \\
Withdrawn quantity during a month (sack) & 300.00 & 282.843 \\
\hline
\end{tabular}

Sources: field survey, 2020

Table 11. costs and returns freezes potatoes stored by cold storage owners in RNS

\begin{tabular}{|c|c|c|}
\hline Costs and benefit per unit & Mean (sack/fed) & Mean (for one ton) \\
\hline \multicolumn{3}{|l|}{ Revenues } \\
\hline Average quantity purchased (sack/year) & 5500 & 1.00 \\
\hline Average purchase price $(\mathrm{kg}=\mathrm{SDG} 45)-(\mathrm{SDG} / \mathrm{sack})$ & 600 & 12,000 \\
\hline Average quantity sales (per/year) & 5500.00 & 1.00 \\
\hline Average selling price ( $\mathrm{kg}=\mathrm{SDG} 80)-(\mathrm{SDG} / \mathrm{sack})$ & 950 & 23020 \\
\hline Total of revenues (SDG/year) & 5225000 & 19000 \\
\hline \multicolumn{3}{|l|}{ Costs } \\
\hline Cost of transport & 34000 & 487.2 \\
\hline Cost of load & 2750 & 120 \\
\hline Cost of rent during period of storage $(5000 * 5)$ & 25,000 & 109 \\
\hline Cost of electricity $(1000 * 5)$ & 5,000 & 22 \\
\hline Cost of government fee & 2,500 & 11 \\
\hline Total operation cost & 2,500 & 11 \\
\hline Total operation cost & $\mathbf{7 1 , 7 5 0}$ & 260.9 \\
\hline Cost of purchase & $3,300,000$ & 12000 \\
\hline Total costs & $3,371,750$ & 12,625 \\
\hline Net Returns & $1,853,250$ & 6,375 \\
\hline
\end{tabular}

Sources: field survey, 2020

\subsection{Wholesalers}

Wholesalers work as intermediaries between farmers/traders and retailers. Wholesalers usually sell in central or town markets, sometimes they sell on an auction basis and the supplier (farmer or trader) and buyer (retailers) pay a particular fee to the wholesaler. The wholesaler is an intermediary who does not sell to the public. In the State the wholesalers buy potatoes crop from the potatoes growers and central markets of the State then sell it to potatoes retailers and cold storage owners and pass the crop to potatoes processors or/and exporter. Most of the wholesalers attend in the crop markets at production areas at postharvesting periods aiming to know prices of potatoes.
Table 12 illustrates a set of activities concerning potatoes wholesalers' activities in River Nile State including locations of potatoes production, main markets of potatoes in the State, main buyers of potatoes, determination of potatoes prices in the state, mechanism of determination of potatoes prices in the state, Sources of information about market prices, main actors who willing to buy potatoes in the State markets and Determination of potatoes selling prices.

Table 12, also depicts the main locations of potatoes production in the State were found as $63.2 \%$ of the production potatoes in Shendi locality, while the other locations namely, Almhmia and Elddamr recorded $21.1 \%$ and $15.8 \%$ respectively. 
Scientific Journal of Agricultural Sciences 2 (2): 158-176, 2020

Table 12. Shows some activities of potatoes wholesalers in River Nile State

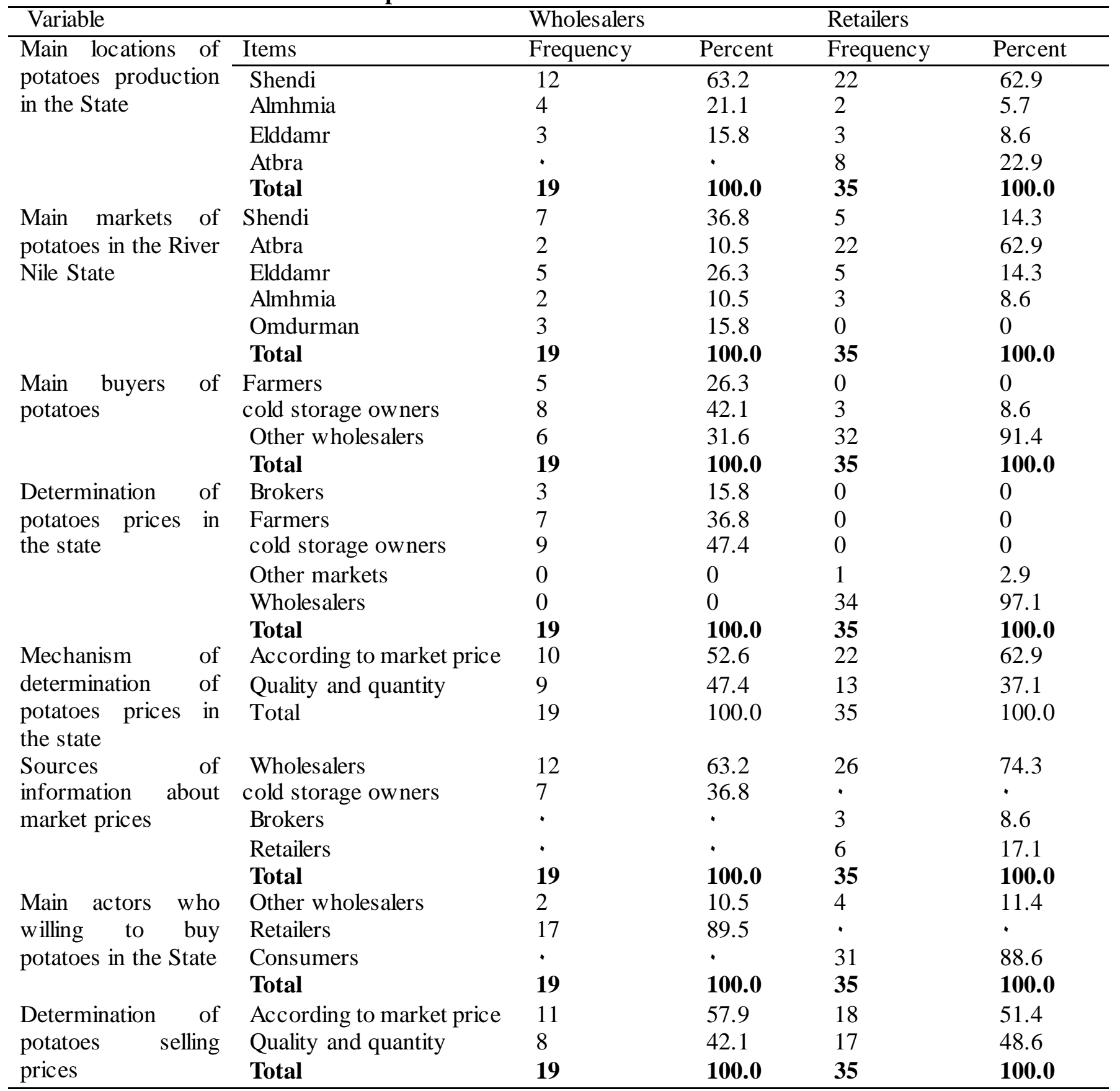

Sources: field survey, 2020.

The study evaluated the main markets of potatoes for wholesalers in the River Nile State were Shendi and Elddamr for $36.8 \%$ and $26.3 \%$ respectively, while the other markets such as Atbra and Almhmia formed only $10.5 \%$. In addition, the research depicted the main buyers of potatoes were cold storages owners, wholesalers and producers buy potatoes by $42.1 \%, 31.6 \%$ and $26.3 \%$ respectively. The mentioned actors contribute in determination of potatoes prices in the state specially the cold storages owners who control the prices by $47.4 \%$, while the

rest percentages $26.3 \%$ and $15.8 \%$ were allocated for producers and brokers respectively. Generally, the mechanism of determination of potatoes prices in the state is based on the marketing prices forces by $52.6 \%$ and $47.4 \%$ formed by quantity and quality of potatoes crop. The study revealed that the main Sources of information about market prices were distributed as $52.6 \%$ for wholesalers and $36.8 \%$ for cold storages owners and the wholesalers intend to sell potatoes in markets for retailers by $89.5 \%$ that means the majority of the sold potatoes go to the retailers, while only 
Elgilany A. Ahmed et al.,2020

$10.5 \%$ of them goes to the other wholesalers. Finally, the determination of potatoes selling prices were found $57.9 \%$ determined by marketing prices forces

and $42.1 \%$ according to quantity and quality of potatoes.

Table 13. Distribution of costs and returns for potatoes wholesalers in River Nile State

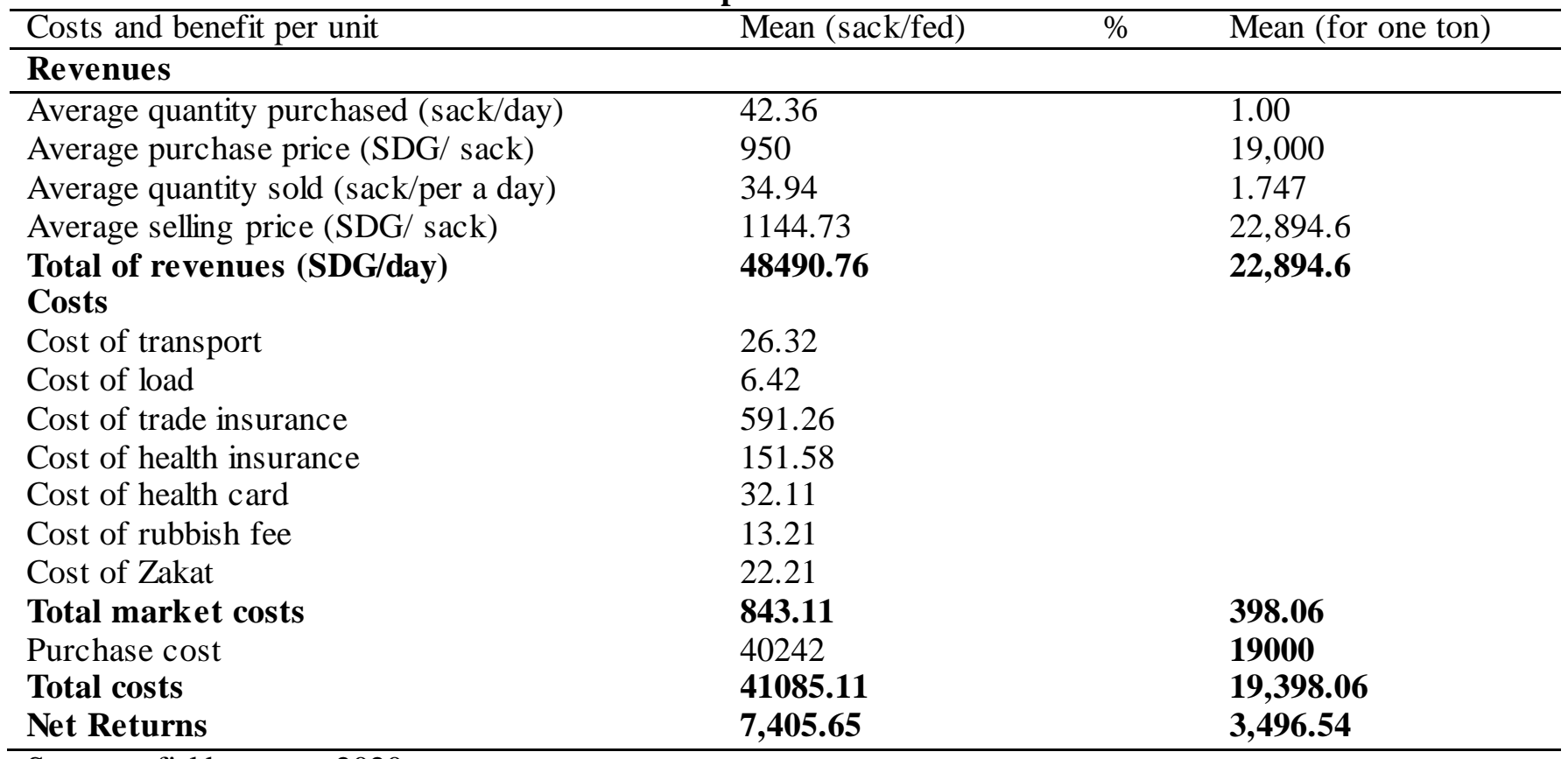

Sources: field survey, 2020

\subsection{Retailers}

Various, ranged from simple small shop and street retailers in village and town markets to modern shops in big towns. Source supplies from wholesalers or directly from production areas in case of some modern retailers. Potatoes retailers are considered as essential actors in potatoes markets of the State. They mainly rec eive the crops from the crop wholesalers in the central markets of the State namely, Shendi, Atbra, Elddamr and Almhmia, and the next chain for retailer is always the consumers who usually by the crop in a Kilogram unit. The study unveiled numerous results with concern to retailers' activities similar to that of potatoes wholesalers' activities in River Nile State consisting locations of potatoes production, main markets of potatoes in the State, main buyers of potatoes, determination of potatoes prices in the state, mechanism of determination of potatoes prices in the state, Sources of information about market prices, main actors who willing to buy potatoes in the State markets and Determination of potatoes selling prices.

The research revealed that the main locations of potatoes production in the State were found as $62.9 \%$ of the production potatoes in Shendi locality, while $22.9 \%, 8.6 \%$ and $5.7 \%$ formed by Atbra, Elddamr and Almhmia respectively. The study evaluated the main markets for retailers where they buy the crop in the River Nile State were Atbara

central market by $63 \%$ and $18.5 \%$ recorded for Shendi and Elddamr for each one. In addition, the research depicted the main buyers of potatoes were wholesalers and cold storages owners buy potatoes by $91.4 \%$ and $8.6 \%$ respectively. The mentioned actors contribute in determination of potatoes prices in the state specially the wholesalers who control the prices for retailers by $97.1 \%$, while only $2.9 \%$ percentages were allocated for retailers. This indicates that the retailers depend on wholesalers to determine potatoes prices in the State markets. Generally, the mechanism of determination of potatoes prices in the state according to retailers' response is based on the marketing prices forces by $62.9 \%$ and $37.1 \%$ formed by quantity and quality of potatoes crop. The study revealed that the main Sources of information about market prices were distributed as $74.3 \%$ for wholesalers, while $17.1 \%$ and $8.6 \% \%$ allocated for retailers and brokers respectively. The study found that the retailers intend to sell potatoes in markets mainly for consumers by about $88.6 \%$, while $11.4 \%$ of them go to the other wholesalers. Finally, the determination of potatoes selling prices according to the retailers reports were found as $51.4 \%$ determined by marketing prices forces and $48.6 \%$ according to quantity and quality of potatoes. This confirms that the marketing preference of actors in potatoes markets in the State is predominant. 
Table 14. Costs and returns for potatoes activities by the retailers in River Nile State

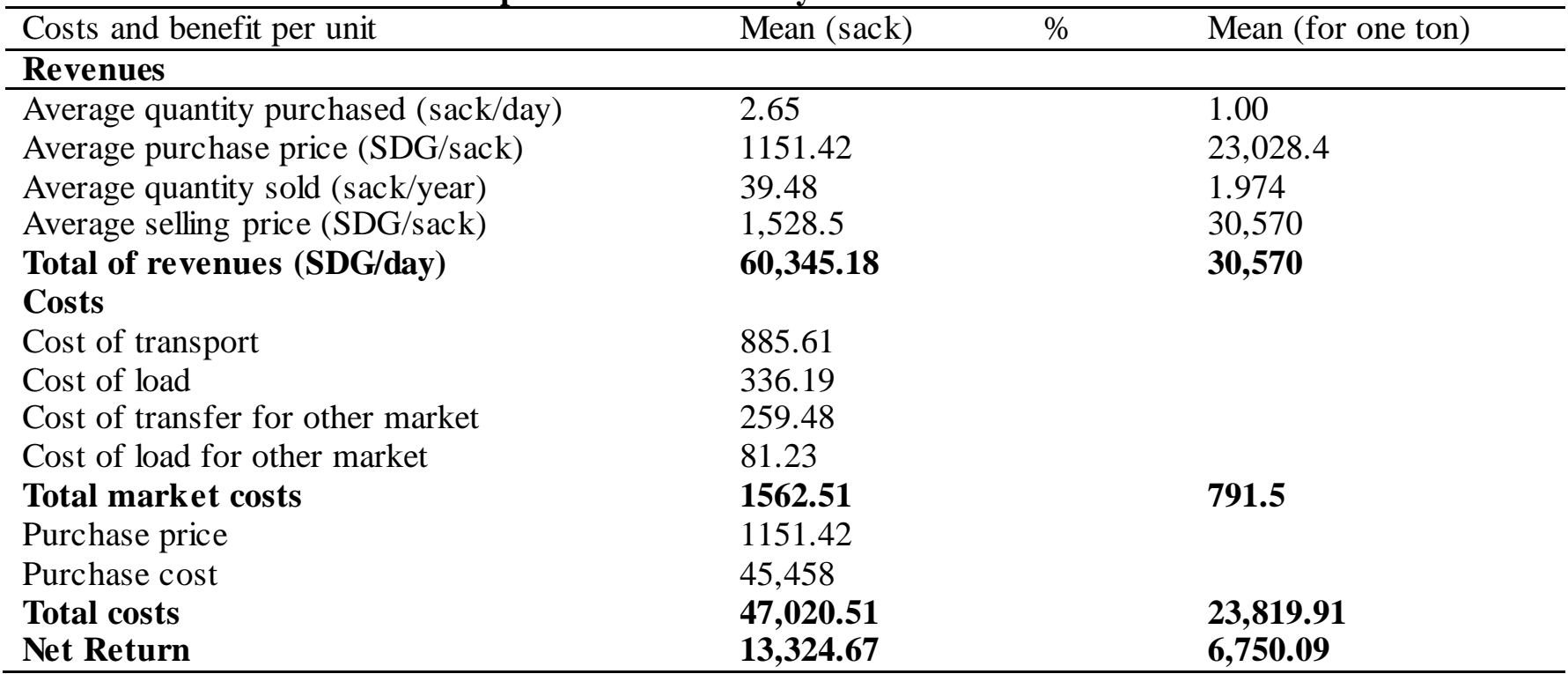

Sources: field survey, 2020

\subsection{Consumers of potatoes}

Despite this humble tuber's popularity, shoppers have generally been offered very little choice about what types of potato to choose from. Supermarkets and some farmers' markets are increasing their range of old and new potato varieties, with myriad tastes and textures. Whichever you buy, they should be firm and well-shaped with no eyes or green patches. The British tend to prefer white-fleshed tatties, whereas the Dutch and Spanish like yellowfleshed potatoes, but color makes little difference to the taste. Once cooked the texture of potatoes can range from smooth, waxy-textured flesh perfect for salads to floury-textured flesh ideal for fluffy mashed potato, so it's important to know what type of potato you've bought before you decide how to cook them.
Consumers of potatoes mainly use potatoes for fast food or to be prepared as the chips and boiled for the kids. The study results appear that the majority of the consumers purchase potatoes from retailers in local markets. The research also considered the important of the potatoes for you as the house keeper, it shows that $73.5 \%$ of the consumers prefer prepared potatoes as fast food, while $26.5 \%$ of them reported potatoes crop important for starch benefits for the children. In other words and based on consumers responds, the most preferred type of cooked potatoes, the study revealed that $55.9 \%$ of the consumers preferred to use the crop for different kind of food, while $23.5 \%$ as boiled potatoes and $20.6 \%$ preferred potatoes chips as shown in figure 6.

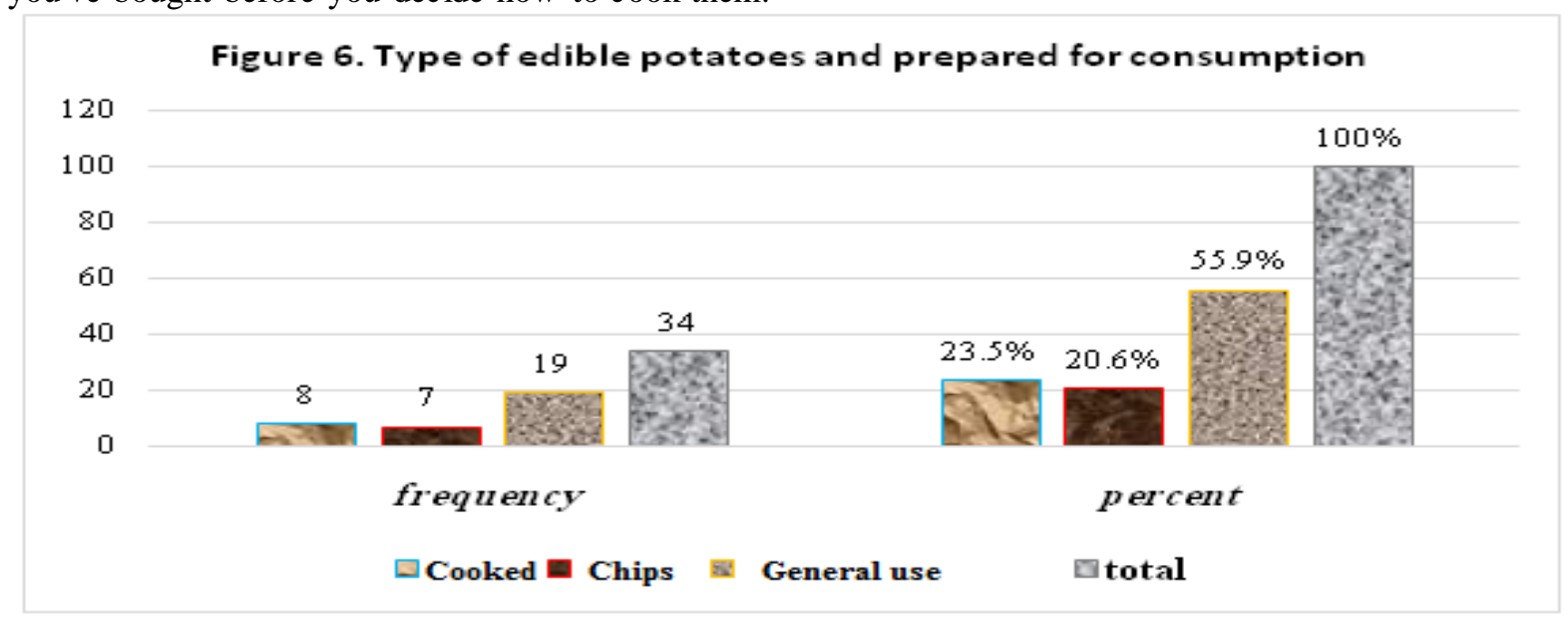

Sources: field survey, 2020 
The research has considered the frequencies of potatoes consumption, it unveiled that $88.2 \%$ of the consumers purchase potatoes every week, while only, $5.9 \%$ of the consumers purchase potatoes every day and the percentage $(5.9 \%)$ every two week indicating that the demand for potatoes high and increasing. The study also aimed to identify the relevant markets for consumers, it revealed that $67.5 \%$ of consumers purchase potato usually from retailers in the local markets, and $17.6 \%$ of them purchase potato from retailers in the central markets of the State, this mean consumers usually require small amount of the crop just mainly for household consumptions, while consumers look to buy potatoes from a particular actors where $70.6 \%$ of the consumers prefer to purchase potatoes from retailers in the local markets, while $20.6 \%$ of them prefer to purchase from retailers in central markets, and only $8.8 \%$ of the consumes prefer to purchase potato from shops cross the road.
The potatoes consumers justify their selection of the mentioned markets due to some reasons, that $50.0 \%$ of the consumers prefer to purchase potatoes for its good quality, while $41.2 \%$ of the consumers prefer to purchase potatoes for its cheap price, and only $8.8 \%$ of the consumers prefer to purchase potatoes for its near place. The study also found that the consumers look for good quality of potatoes with a certain criteria. It reported that $67.6 \%$ of the consumers preferred potatoes based on the form and volume; while $26.5 \%$ of the consumers purchase potato according to the variety or type, and there are only $5.9 \%$ choose potato for purchase according to the price. The consumers usually prefer fresh potatoes for consumption. The results shows that $73.5 \%$ of the consumers don't used cold storages or freezer for saving their potatoes, while $26.5 \%$ of the consumers like to use cold storage or freezer for saving potatoes for a long time.

Table 15. Distribution of the consumers according to potatoes criteria, actors and mark ets

\begin{tabular}{|c|c|c|c|}
\hline Variables & & & mers \\
\hline The frequencies of potatoes & Items & Frequency & Present \\
\hline consumption & Daily & 2 & 5.9 \\
\hline & Weekly & 30 & 88.2 \\
\hline & Every two week & 2 & 5.9 \\
\hline & Total & 34 & 100.0 \\
\hline Identification of relevant & Retailers in the central markets & 6 & 17.6 \\
\hline sources and markets for & Retailers in the local markets & 26 & 76.5 \\
\hline consumers & Shops cross the road & 2 & 5.9 \\
\hline & Total & 34 & 100.0 \\
\hline Consumers look to buy & Retailers in the central markets & 7 & 20.6 \\
\hline potatoes from a particular & Retailers in the local markets & 24 & 70.6 \\
\hline actors & Shops cross the road & 3 & 8.8 \\
\hline & Total & 34 & 100.0 \\
\hline Potatoes consumers justify & Cheap prices & 14 & 41.2 \\
\hline reasons of selection of the & Good quality & 17 & 50.0 \\
\hline mentioned markets & Near place & 3 & 8.8 \\
\hline & Total & 34 & 100.0 \\
\hline Consumers prefer good & Form and volume & 23 & 67.6 \\
\hline quality of potatoes with basic & Variety or type & 9 & 26.5 \\
\hline criteria & Price & 2 & 5.9 \\
\hline & Total & 34 & 100.0 \\
\hline
\end{tabular}

Sources: field survey, 2020

Table 16 illustrates the distribution of prices (SDG), and also it shows the withdrawn consumers according to purchased quantities $(\mathrm{kg})$ and quantity during a month per sack in River Nile State. Table 16. Distribution of potatoes consumers according to purchased quantities and prices

\begin{tabular}{lll}
\hline Variable & Consumers & \\
\cline { 2 - 3 } & Mean & SD \\
\hline Quantity (kg) & 1.47 & .873 \\
Prices (SDG) & 32.64 & 8.637 \\
\hline
\end{tabular}

Sources: field survey, 2020 
Table 17 summarizes and represents gross profit margins (GPM) and gross marketing margins (GMM). The GPM is known as the percentage of revenue that is actual profit before adjusting for operating costs, such as marketing, overhead, and salaries. The two factors that determine gross profit margin are revenue and cost of goods sold (COGS). COGS is what it directly costs the company to make a product, while the gross marketing margins (GMM) is defined as the percentage of revenue that is actual profit before adjusting for operating costs, such as marketing, overhead, and salaries. The two factors that determine gross profit margin are revenue and cost of goods sold (COGS). COGS is what it directly costs the company to make a product. Also the table shows the average purchase prices, selling prices, costs, revenues, and profits for each stage of potatoes production as well as marketing stages among potatoes value chain in the River Nile State.

Table 17. Profits and marketing margins of one ton of potatoes for different actors

\begin{tabular}{ll}
\hline Items & Value (SDG/ton) \\
\hline Producers: & 7634.53 \\
\hline Purchase price of potatoes & 1450 \\
Production expenses & 12000 \\
Selling price of potatoes & 4365.47 \\
Gross marketing margin (GMM) & 4365.471 \\
Gross profit margin (GPM) & \\
Cold storage owner: & 12000 \\
Purchase price of potatoes & 260.9 \\
Operation expenses & 19000 \\
Selling price of potatoes & 7000 \\
Gross marketing margin (GMM) & 6375 \\
Gross profit margin (GPM) & \\
Wholesalers: & 19000 \\
Purchase price of potatoes & 398.06 \\
Marketing expenses & 22894.6 \\
Selling price of potatoes & 3894.6 \\
Gross marketing margin (GMM) & 3496.54 \\
Gross profit margin (GPM) & \\
Retailers: & 23028.4 \\
Purchase price of potatoes & 791.5 \\
Marketing expenses & 30570 \\
Selling price of potatoes & 7541.6 \\
Gross marketing margin (GMM) & 6750.09 \\
Gross profit margin (GPM) & \\
\hline Source: Fid survey, & \\
\hline
\end{tabular}

Source: Field survey, 2020

From the table it was noticed that the retailers achieved the highest gross marketing margin (GMM) and gross profit margin (GPM) as SDG 7541.6 and SDG 6750.09 respectively, ranked by cold storage owner for one ton potatoes marketing, while the wholesalers were formed the lowest percentages. On the other hand, the producers recorded the highest cost of production for the crop appeared as SDG 1450 compared to potatoes actors of the crop value chain. Figure 7 also illustrates the percentages share of potatoes basic actors among the crop value chain in River Nile State. 


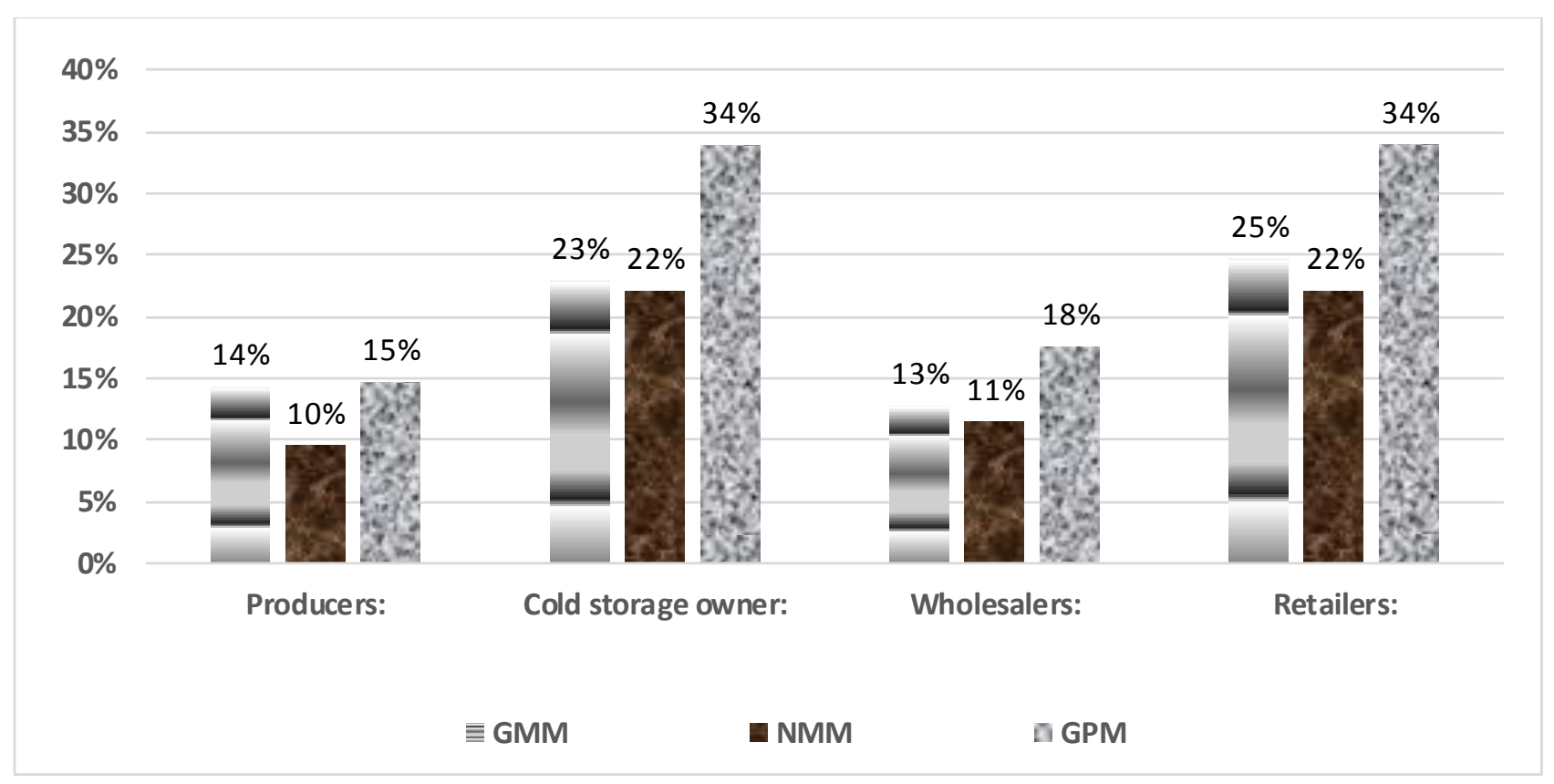

Figure 7. Percentage share of basic actors in potatoes value chain in the State

Source: Field survey, 2020

Table 18 depicts the marketing share and profit margin for potatoes different actors of the crop chain. The author used Excel computer software program to assess the share of gross profit margins (GPM) and gross marketing margin (GMM) for different actors of potatoes value chain per ton, in River Nile State. It's clear that share of benefit is the key factor to create a powerful relationship among the crop actors. The research revealed that the potatoes retailers added the highest share of marketing and profit margin $(33 \%, 32 \%)$ to total value, while the share of the other actors were found as $(31 \%, 30 \%)$,
$(19 \%, 21 \%)$, and $(17 \%, 17 \%)$ for cold storage owner, producers and wholesalers respectively. The crop retailers gained the highest portion of benefits because they usually purchase the crop directly from potatoes producers as well as from cold storage owners this reason contributes significantly in lowering the expenses and also lead to avoid the other crop brokers. This study also proves that the contribution of the Marketing Efficiency Rate (MER) was high and recorded $75 \%$, while the producer share (PS) was recorded $25 \%$.

Table 18. Share of gross profit margins (GPM) and gross marketing margin (GMM) for different actors of potatoes value chain per ton, in River Nile State.

\begin{tabular}{lccccc}
\hline \multicolumn{1}{c}{ Items } & Producers & Cold storage owners & Wholesalers & Retailers & Total \\
\hline GMM & 4365.47 & 7000 & 3894.6 & 7541.6 & 22801.67 \\
share of GMM\% & 19 & 31 & 17 & 33 & 100 \\
GPM & 4365.471 & 6375 & 3496.54 & 6750.09 & 20987.101 \\
share of GPM\% & 21 & 30 & 17 & 32 & 100 \\
TGMM & & & & & 22801.67 \\
TGPM & 1450 & 260.9 & 398.06 & 791.5 & 20987.101 \\
OE & & & $25 \%$ & & \\
PS & & & $75 \%$ & & \\
MER & & & & & \\
\hline
\end{tabular}

Source: Field survey, 2020

\section{Conclusion and policy implication}

Successful or failure of agricultural sector are related to government policies, thus the most of the root causes to the constraints of the potatoes subsectors is related to the State policies which have not expressed a clear agriculture strategy especially for rural areas like north Sudan region. Other hindrances are concerned to certain key actor such as traders and wholesalers in potatoes value chain, who control the whole process along the crop chain by financing the crop growers for all their input materials. In addition, a few constraints are also related to the farmers' 


\section{Scientific Journal of Agricultural Sciences 2 (2): 158-176, 2020}

culture that resists application of modern technologies as well as new ideas. Numerous points obtained at the conclusion and policy implication part as follow:

1. Potatoes producers should develop aw areness:

a. Cultural practices suitable to different agro-ecological zones, irrigation supply, pesticides and fertilizers use, and importance of crop rotation.

b. Appropriate management practices for the control of major pest and diseases in the existing groves and for the protection of new ones.

c. Provision of facilities for training technician, extension agents and growers' proper pre-and harvest technologies for potatoes production and marketing. Interventions concerning the crop growers should aim to raise their aw areness how to think as if as small entrepreneur

d. Promotion of techniques for the postharvest handling, processing and making of potatoes and for utilization of byproducts.

e. Identification of superior varieties with emphasis on adoption to non-conventional growing areas and high quality varieties for local consumption as well as exportation.

f. Encouragement of expansion of potatoes growing at potential areas in the State and by supplying the private sector with suitable planting material and recommendations on appropriate cultural practices.

g. Importance of working to gather in small groups or cooperative associations in order to reduce share and minimize costs of production (using proper methods of calculating production costs and keeping records and other basic business management), distribution and marketing, protect each other from marketing instability through share of experiences and strengthen the bargaining power within the chain.

h. Different available options regarding access and process to agricultural finance.

2. Potatoes retailers, wholesalers, and cold storage owners should develop aw areness:

a. Distribution and transportation of the crop, marketing and exhibiting at trade fairs. b. The potential of investing in storage facilities of potatoes (cold storages and cold trucks)

c. For fair trade and ethical trading principles.

d. Correct and feasible selection for new markets.

e. Global standards of international trade and methods of adopting them, and

f. Fair trade and ethical trading principles.

3. Governmental institutions should:

a. Play a role in providing financial support to the crop growers to gradually break the tight grip of traders and wholesalers over the whole value chain.

b. Encourage greater facilitation by financial institutions for businesses to access finance and micro credit.

c. Enforce implementation of an agriculture calendar maximize production, reduce risk, and competitiveness is increased through forming a steering committee with core members who are active key players from the whole value chain.

d. Establishment of a training centre for specialized crops.

e. Institutional and human capacity building. To learn them step by step about the way of how to increase the crop yield of their farmland per unit area.

f. Improvement of techniques for genetics, breeding and propagation (i.e. Potatoes breeding research is required for evolving new varieties which give high yield and should have resistant against disease and pest attacks). The main service provider for this part in Sudan is Agricultural Research Corporation (ARC), the flowing part is concerning with this important institution in the country.

Potatoes research in Sudan is managed mainly by Agricultural Research Corporation (ARC), it addresses a number of issues anticipated to develop the crop sub-sector, and these issues are as follow:

1) Sustainable potatoes production techniques, potential cropping systems and appropriate plant genetic resources explored, identified and conserved in various regions of Sudan in accordance with the comparative advantage and food security requirements.

2) Strengthened national capacity in protection and prevention of potatoes pests and diseases; and 
3) Developed potatoes' agricultural research processes, systems and programs.

The key expected results will be achieved through several interventions as follows:

a) Assess and evaluate the present situation of potatoes diversity and production.

b) Review the agro-climatic data of the areas and agricultural resources availability for sustainability of potatoes cultivation.

c) Review and assess the current potatoes research strategies and propose key interventions to enhance development of efficient agricultural practices techniques.

d) Explore the potential areas for cultivation of potatoes in River Nile State and hence at the macro levels.

e) Assess the local potatoes selections and develop standard protocol for identification and regional comparative advantage.

f) Identify key technical production constraints to be overcome.

g) Identify harvest, post-harvest and marketing constraints and develop improved techniques and channels.

h) Identify needs of international technical assistance to support the development of potatoes industry.

i) Assess the local technical support capacity for potatoes development and identify the necessary components of a comprehensive training program aims at providing the technical staff and the stakeholders with the required knowledge.

j) Identify the investments in terms of manpower, equipment, internal and external training that would be required to overcome the technical constraints faced by the relevant regions as related to development of the potatoes industry.

\section{REFERENCES}

Abdel Magid HM (1991). Productivity of wheat and alfalfa under intercropping. Exp. Agr. 27, 391-395.

Algizouli TA (2007). Economics of Potato Production and Marketing in Khartoum State, Sudan. Unpublished thesis, University of Khartoum, Faculty of Agriculture, Department of Agricultural Economics.

Abdallah S, Fan I (2012) Framework for egovernment assessment in developing countries: Case study from Sudan. Electronic Government, an International Journal 92: 158-177.
Bardhan P, Udry C (1999) Development microeconomics. Oxford University Press. Evenson RE, Gollin D (2003) Assessing the impact of the green revolution, 1960-2000. Science 300:758-762.

Singh NP, Hardway AK, Kumer A, Singh KM (2004). Modern technology on vegetables production. International Book Distributing Company, India.

FAO (2012). Food and Agriculture Organization of the United Nations, FAOSTAT database 2015.

FAO (2015). Food and Agriculture Organization of the United Nations. Potatoes and ledavy greem vegheatbles: value chain analysis (Akkar, Lebanon) / ILO Regional Office for Arab States - Beirut: ILO, 2015. ISBN 9789221302087; 9789221302094 (web pdf),ILO Regional Office for Arab States.

Ministry of Agriculture and Animal Wealth and Irrigation of Khartoum State: Field Administration reports (2000-2007), General Administration of Agriculture Services.

Richard Bowen, W. 'Water engineering for the promotion of peace". 1944-3994 / 1944-3986 (C) 2009. Desalination Publications. doi: 10.5004/dwt.2009.170. 1 (2009) 1-6. 2009. 


\title{
الملخص العربي
}

\section{تحليل وتطوير سلسلة القيمة لمحصول البطاطس بولاية نهر النيل في السودان}

\author{
الجيلاني عبدالحفيظ أحمد* ، حامد حسين الفكي ، عباس السر ، هنادي الفاضل ، أبكر إسماعيل

$$
\text { مركز البحوث الاقتصادية والسياسات الزراعية ،هيئة البحوث الزراعية - السودان }
$$

حاليا وفي جميع أنحاء العالم، يتزايد القلق بثأن نظوير إنتاج المحاصيل الغذائية والنقدية الرئيسية لتلبية الطلب على النمو السكاني وتحقيق استدامة النظام المزرعى. يعتبر محصول البطاطس من أكثر المحاصيل التى يمكن التوسع فيها بولاية نهر النيل والتي يمكن أن تحقق هذا الغرض. يهدف هذا البحث إلى وصف وتحليل وتطوير سلسلة القيمة لمحصول البطاطس. اعتمد البحث على البيانات الأولية والثانوية. طبقت

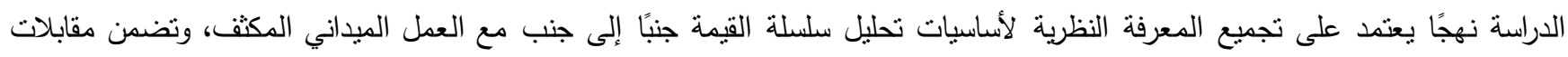
مختلفة شملت عـ منتجًا للبطاطس و 19 ناجر جملة وهب تاجر تجزئة واثثين من مديري المخازن المبرده و عـ مستهلكًا. تقدم العناصر الفاعلة

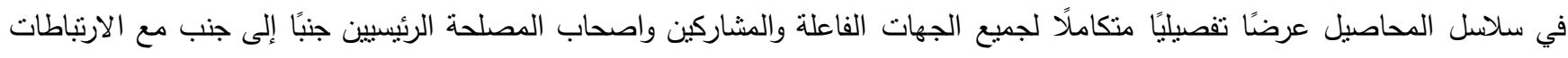

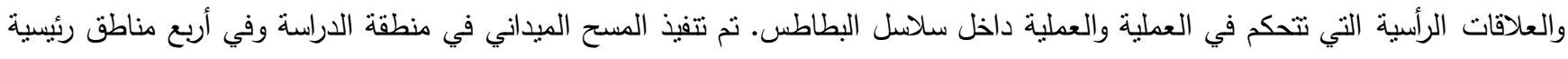

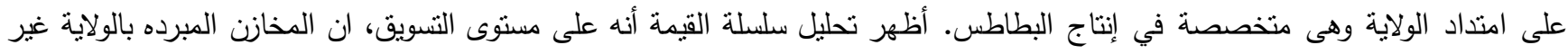
كافية لحفظ البطاطس، وان الخدمات الإرشادية ضعيفة على المستويات المختلفة من سلسلة المحاصيل. ومع ذلك، ولمعالجة هذه القيود، فإن تعاون أصحاب المصلحة مما يعني ضمناً المنظمات الزراعية الوطنية والدولية والمؤسسات الحكومية والقطاع الخاص من شأنه أن يعزز الستدامة نظام 